\title{
ANALISIS PEMBELAJARAN DISIPLIN MAHASISWA BARU TAHUN AKADEMIK 2020 FKIP UNTAN DI PONTIANAK
}

\author{
Priyo Saptomo \\ FKIP Universitas Tanjungpura Pontianak \\ Email:priyo.saptomo@hukum.untan.ac.id
}

\begin{abstract}
This research is entitled "Analysis of New Student Discipline Learning for Academic Year 2020 FKIP Untan in Pontianak". The formulation of the problem in this research is How Discipline Learning for New Students in the 2020 Academic Year of FKIP Untan in Pontianak. The method used is descriptive method. The form of research is descriptive qualitative. Data collection techniques in this study were: direct communication with data collection tools, interview guides, direct observation using observation sheet data collection tools, documentary studies using data file data collection tools. The results of the study are as follows: Based on research that has been conducted on FKIP Untan students, it is known that there is no difference in learning traffic discipline based on attitudes towards the police (FA). This can be seen from the results obtained, where FA got a value of 1.705 with a $p$ value of 0.186 ( $p>0.05)$. When viewed based on the categorization of variable values, positive values with a score range of 75 get a result of $14 \%$ with a frequency of 7 men and 10 women. On a neutral value with a score range of 5074 get $81 \%$ results with the same frequency between men and women as many as 49 people. Meanwhile, the negative categorization got a result of 5\% with the frequency of 4 men and 2 women.
\end{abstract}

Keyword : Analysis of Student Discipline Learning.

\section{PENDAHULUAN}

Kepatuhan dalam disiplin belajar mahasiswa didalam implementasinya masih terlihat belum pada diri mahasiswa hal ini dikarena kurang kesadaraan dari dalam diri mahasiswa. Kedisiplin dala belajar masih rasakan belum optimal hal ini dikarenakan kurang dukungan dari berbagai aspek baik dari internal serta eksternal. Negara Indonesia merupakan negara hukum yang telah diamanatkan Pasal 1 ayat 3 Undang-Undang Dasar Negara Republik Indonesia Tahun 1945, atas dasar tersebut segala tindakan masyarakat harus sesuai dengan hukum. Hukum adalah seperangkat aturan yang harus ditaati dan apabila melanggar akan mendapat saksi, Hal tersebut sesuai dengan pendapat Borst hukum yaitu keseluruhan peraturan bagi kelakuan atau perbuatan manusia didalam masyarakat yang pelaksanaannya dapat dipaksakan dan bertujuan mendapat tata atau keadilan.Hukum adalah suatu aturan yang dibuat untuk dipatuhi oleh semua warga negara. Hukum tertulis adalah hukum yang telah dicantumkan dalam peraturan Perundang-Undangan seperti KUHP, sedangkan hukum tidak tertulis adalah hukum yang berkembang dalam adat istiadat Masyarakat. Kesadaran hukum adalah cara pandang atau pemahaman hukum oleh masyarakat. Kesadaran hukum seharusnya sudah ada dalam diri individu seperti dalam menaati lalu lintas demi keselamatan bersama adapun pelanggaran yang banyak terjadi adalah tidak membawa 
SIM, STNK, berboncengan lebih dari dua orang, tidak memakai helm, menerobos lampu merah, dan tidak lengkapnya kendaraan bermotor (tidak adanya nomor kendaraan, kaca spion tidak lengkap, knalpot tidak sesuai standar nasional, dan memperkecil ukuran ban, menggunakan $\mathrm{Hp}$ saat berkendara, memodifikasi motornya sehingga membahayakan keselamatan lalu lintas.

Peningkatan jumlah sepeda motor dari tahun ke tahun terus mengalami penambahan sehingga hal tersebut mempengaruhi kehidupan lalu lintas sehingga timbul beberapa permasalahan antara lain: sering terjadi kemacetan karena jumlah sepeda motor yang tinggi tidak diimbangi dengan pelebaran jalan raya; sering terjadi kecelakaan karena kelalaian pengemudi atau yang tidak disengaja seperti motor yang sudah tidak layak dikendarai tetapi masih tetap dikendarai, ini dapat membahayakan pengemudi sendiri dan orang lain; sering terjadi kejahatan seperti perampasan benda-benda berharga seperti handphone, perhiasan, dompet, ini biasa terjadi saat lampu merah atau jalanan yang sepi. Oleh karena itu, polisi sebagai aparatur pemerintah yang bertugas untuk melindungi dan mengayomi masyarakat dituntut untuk meningkatkan penanganan masalah lalu lintas secara cermat sehingga tujuan lalu lintas yang tertib, aman, dan lancar dapat terwujud.Dari pengamatan di lapangan yang penulis lakukan dalam hal ini di lingkungan Fakultas Keguruan dan Ilmu Pendidikan Universitas Tanjungpura, pelanggaran yang terjadi selalu berulang setiap harinya.

Jenis pelanggaran tersebut seperti tidak menyalakan lampu utama di siang hari sebagaimana yang tertulis pelanggaran ini tertera dalam Undang-Undang Nomor 22 Tahun 2009 Pasal 107 ayat (2) junto Pasal 293 ayat 2, tidak memakai helm sebagaimana yang tertulis pelanggaran ini tertera dalam UndangUndang Nomor 22 Tahun 2009 pasal 291 ayat 1 dan 2, tidak memakai spion, pelanggaran ini tertera dalam Undang-Undang Nomor 22 Tahun 2009 pasal 285 ayat 1 , melanggar rambu rambu lalu lintas yang terpasang, contoh larangan parkir di area yang telah terpasang rambu dilarang parkir. Pelanggaran ini tertera dalam UndangUndang Nomor 22 Tahun 2009 pasal 287 ayat 3. Kemudian menggunakan alat komunikasi saat berkendara, pelanggaran ini tertera dalam Undang-Undang Nomor 22 Tahun 2009 pasal 283. Pelanggaranpelanggaran diatas merupakan sedikit dari sekian pelanggaran yang telah terjadi dan mereka bersikap seolah tidak tahu atau belum mengetahui Undang-Undang tersebut. Berdasarkan uraian latar belakang diatas maka perlu dilakukan penelitian tentang "Analisis Pembelajaran Disiplin Mahasiswa Baru Tahun Akademik 2020 FKIP Untan Di Pontianak “.

Masalah dalam penelitian ini adalah "Bagaimana Pembelajaran Disiplin Mahasiswa Baru Tahun Akademik 2020 FKIP Untan Di Pontianak?". Adapun tujuan yang ingin dicapai dari penelitian ini berdasarkan masalah adalah untuk mengetahui Pembelajaran Disiplin Mahasiswa Baru Tahun Akademik 2020 FKIP Untan Di Pontianak. Analisis menurut Wiraldi (2013) adalah aktivitas yang memuat sejumlah kegiatan seperti mengurai, membedakan, memilah sesuatu untuk digolongkan dan dikelompokkan kembali menurut kriteria tertentu kemudian dicari kaitannya dan ditaksir maknanya. Analisis adalah gambaran atau uraian terhadap suatu komponen. Disiplin adalah aturan yang dibuat untuk dipatuhi serta ditaati. 


\section{METODE PENELITIAN}

Penelitian kualitatif adalah penelitian tentang riset yang bersifat deskriptif dan cenderung menggunakan analisis. Proses dan makna (perspektif subjek) lebih ditonjolkan dalam penelitian kualitatif. Landasan teori dimanfaatkan sebagai pemandu agar fokus penelitian sesuai dengan fakta di lapangan. Selain itu landasan teori ini juga bermanfaat untuk memberikan gambaran umum tentang latar penelitian dan sebagai bahan pembahasan hasil penelitian. Terdapat perbedaan mendasar antara peran landasan teori dalam penelitian kuantitatif dengan penelitian kualitatif. Dalam penelitian kualitatif peneliti bertolak dari data, memanfaatkan teori yang ada sebagai bahan penjelas, dan berakhir dengan suatu "teori".

Pendekaan metode evaluasi menurut Dunn dibagi dalam tiga kelompok yaitu pendekatan evaluasi semu pendekatan,evaluasi formal dan pendekatan keputusan teori. Dari ketiga bentuk evaluasi dapat dibedakan dari tujuannya,asumsinya bentuknya dan teknik evaluasinya Adapun yang paling cocok dan relevan dengan evaluasi Pembelajaran Disiplin Mahasiswa Baru Tahun Akademik 2020 FKIP Untan Di Pontianak adalah bentuk evaluasi formal dengan tujuannya untuk mendiskripsikan hasil informasi yang terpercaya untuk diumumkan secara formal sebagai bahan kebijakan program studi untuk Pembelajaran Disiplin Mahasiswa Baru Tahun Akademik 2020 FKIP Untan Di Pontianak.Desain evaluasi mencakup suatu proses dan perangkat rencana atau hasil tertuli (Brinkerholf, Robert. Et all, 1983.) Disain evaluasi merupakan bentuk rencana evaluasi yang meliputi komponen: fokus evaluasi cara menjaring informasi, mengolah informasi yang diperoleh, membuat laporan dan melakukan reviu atau peninjauan kembali terhadap semua langkah evaluasi yang dilakukan.

\section{HASIL DAN PEMBAHASAN Hasil Penelitian}

Berdasarkan penelitian yang telah dilakukan pada mahasiswa FKIP Untan, diketahui bahwa tidak ada perbedaan pembelajaran disiplin berlalu lintas berdasarkan sikap terhadap polisi (FA). Hal tersebut dilihat dari hasil yang didapatkan, dimana FA mendapatkan nilai sebesar 1,705 dengan nilai $p$ sebesar 0,186 $(\mathrm{p}>0,05)$. Apabila dilihat berdasarkan kategorisasi nilai variabel, nilai positif dengan rentang skor 75 mendapatkan hasil sebesar $14 \%$ dengan frekuensi laki-laki sebanyak 7 orang dan perempuan sebanyak 10 orang. Pada nilai netral dengan rentang skor 50-74 mendapatkan hasil $81 \%$ dengan frekuensi yang sama antara laki-laki dan perempuan sebanyak 49 orang. Sedangkan pada ketegorisasi negatif mendapatkan hasil sebesar 5\% dengan frekuensi laki-laki sebanyak 4 orang dan perempuan sebanyak 2 orang.

\section{Pembahasan Penelitian}

Berdasarkan hasil penelitian yang dilakukan peneliti berkaitan dengan Analisis Pembelajaran Disiplin Mahasiswa Baru Tahun Akademik 2020 FKIP Untan Di Pontianak, dimana menunjukkan tingkat disiplin belajar mahasiswa dalam kategori yang baik hal ini terlihat dari persentase $81 \%$ tingkat disiplin belajar mahasiswa. Dengan tingkat disiplin belajar dalam kategori baik ini merupakan cerminan kepatuhan mahasiswa dalam mematuhi aturan yang telah ditetapkan difakultas. Disiplin belajar mahasiswa disebabkan berbagai faktor yang mempengaruhi, faktor internal yang berasal dari diri mahasiswa sendiri yang menyebabkan kurangnya disiplin seperti telat hadir, serta keluar masuk kelas. 
Sedangkan faktor eksternal berasal dari faktor luar disebabkan dari lingkungan tempat tinggal serta faktor pergaulan yang bisa menyebabkan tingkat disiplin belajar mahasiswa berkurang. Untuk meningkatkan tingkat disiplin belajar mahasiswa diperlukan dukungan dari semua faktor baik secara internal maupun eksternal. Didalam disiplin diperlukan kesadaran mahasiswa untuk secara sadar untuk disiplin dengan membiasakan diri agar terbiasa dengan lingkungan pembelajaran serta adanya dukungan moril dari orang tua atau lingkungan keluarga. Didalam disiplin belajar tentunya mahasiswa membutuh mental yang kuat untuk memotivasi diri agar bisa memahami pembelajaran secara utuh, dengan adanya kepatuhan mahasiswa ini akan menciptakan iklim belajar yang lebih baik sehingga tujuan pembelajaran.

\section{SIMPULAN DAN SARAN}

\section{Simpulan}

Berdasarkan hasil penelitian, Pembelajaran Disiplin Mahasiswa Baru Tahun Akademik 2020 FKIP Untan Di Pontianak berada dalam kategori baik hal ini dikarenakan tingkat kesadaran mahasiswa dalam displin terlihat kesadaranya seperti taat terhadap aturan yang berlaku. Analisis Pembelajaran Disiplin Mahasiswa Baru Tahun Akademik 2020 FKIP Untan Di Pontianak, dimana menunjukkan tingkat disiplin belajar mahasiswa dalam kategori yang baik hal ini terlihat dari persentase $81 \%$ tingkat disiplin belajar mahasiswa. Dengan tingkat disiplin belajar dalam kategori baik ini merupakan cerminan kepatuhan mahasiswa dalam mematuhi aturan yang telah ditetapkan difakultas. Disiplin belajar mahasiswa disebabkan berbagai faktor yang mempengaruhi, faktor internal yang berasal dari diri mahasiswa sendiri yang menyebabkan kurangnya disiplin seperti telat hadir, serta keluar masuk kelas. Sedangkan faktor eksternal berasal dari faktor luar disebabkan dari lingkungan tempat tinggal serta faktor pergaulan yang bisa menyebabkan tingkat disiplin belajar mahasiswa berkurang. Untuk meningkatkan tingkat disiplin belajar mahasiswa diperlukan dukungan dari semua faktor baik secara internal maupun eksternal. Didalam disiplin diperlukan kesadaran mahasiswa untuk secara sadar untuk disiplin dengan membiasakan diri agar terbiasa dengan lingkungan pembelajaran serta adanya dukungan moril dari orang tua atau lingkungan keluarga. Didalam disiplin belajar tentunya mahasiswa membutuh mental yang kuat untuk memotivasi diri agar bisa memahami pembelajaran secara utuh, dengan adanya kepatuhan mahasiswa ini akan menciptakan iklim belajar yang lebih baik sehingga tujuan pembelajaran

\section{Saran}

Berdasarkan hasil penelitian, maka saran-saran yang dapat diberikan sebagai berikut: Diharapkan kepada mahasiswa agar lebih serius dan teliti serta bersungguh-sungguh dalam mengikuti pembelajaran serta selalu disiplin.

\section{DAFTAR RUJUKAN}

Abdul A.R. 2017. Psikologi Sosial : Integrasi Pengetahuan Wahyu dan Pengetahuan Empirik. Jakarta : Raja Grafindo Persada

Abdullah. 2001. Seks, Gender dan Reproduksi Kekuasaan. Yogyakarta : Pusat Tarawang Press

Andi Offset. . 2013. Sikap Manusia : Teori dan Pengukuran.Yogyakarta : Pustaka Pelajar. . 2015. Metode Penelitian. Yogyakarta : Pustaka Pelajar.

Argyle, M. 1994. The Psychology Of Interpersonal Behavior. Fifty Edition. New York : Penguin Books 
Arikunto, S. 2006. Prosedur Penelitian Suatu Pendekatan Praktik. Jakarta : PT Reneka Cipta . 2013. Dasar-dasar evaluasi pendidikan (Edisi 2). Jakarta: Bumi Aksara.

Azwar, Saifuddin. 2003. Penyusunan Skala Psikologi. Yogyakarta :

Blass, Thomas. 1999. The Milgram Paradigm After 35 Years : Some Things We Now Know About Obidience to Authority. Journal of Applied Social Pscyhology. Baron and Byrne. 2004. Psikologi Sosial Edisi Kesembilan.Jakarta :

Crawford, J., Kippax, S., Onyx, J., Gauh, U., and Benton, P. 1992. Emotion and Gander : Constructing Meaning. London :
Erlangga. . 2005. Psikologi Sosial (terjemahan).Jakarta : Erlangga.

Feldman. 2003. Essentials of Understanding Psychology. New York : McGrawHill Companie, Inc.

Garunhawaca Saam, Z. dan Wahyuni, Sri. 2014. Psikologi keperawatan. Jakarta: Rajawali Pers

Hartono. 2006. Kepatuhan dan Kemandiria Santri. Ibda'. Vol 4, No.1, STAIN Purwokerto Hurlock, E.B. 1990. Suatu Pendekatan Sepanjang Rentang Kehidupan. Jakarta : Erlangga

Kartono, Kartini. 1992. Patologi Sosial2 (Kenakalan Remaja). Jakarta: Raja Grafindo Persada. 